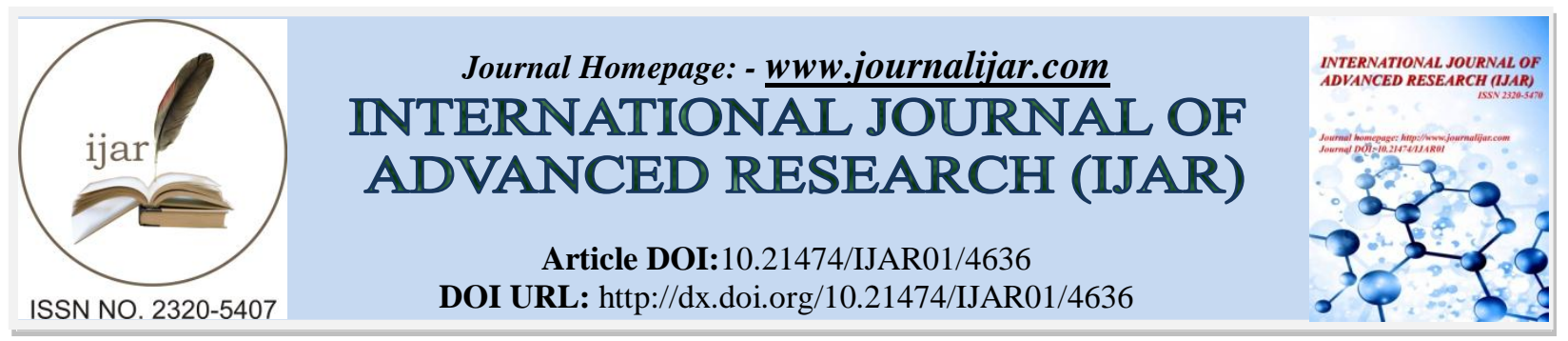

RESEARCH ARTICLE

\title{
HEAVY METAL STATUS OF DIFFERENT LAND USES IN SOILS OF NORTH WESTERN
} HIMALAYAS, H.P-INDIA.

\author{
Ravinder Kumar ${ }^{1}$, S. S. Paliyal ${ }^{2}$ and Sanjay Kumar Sharma ${ }^{3}$. \\ 1. Ph.D Doctoral Scholar, Department of Soil Science H.P. Krishi Vishavavidyala, Palampur176062, India. \\ 2. Principle Scientist, (Soil Science) Krishi Vigyan Kendra, Sirmour at Dhaulakuan (H.P.) 173031 \\ 3. Principle Scientist, (Soil Science) H.P. Krishi Vishavavidyala, Palampur176062, India.
}

\section{Manuscript Info}

Manuscript History

Received: 28 April 2017

Final Accepted: 30 May 2017

Published: June 2017

Key words:-

Heavy metal, North Western HimalayaH.P

\section{Abstract}

Heavy metals, such as cadmium, copper, lead, chromium and nickel are major environmental pollutants, particularly in areas with high anthropogenic pressure. Heavy metal accumulation in soils is of great concern in agricultural production due to the adverse effects on food safety and marketability, crop growth due to phytotoxicity, and environmental health of soil organisms. The influence of plants and their metabolic activities affects the geological and biological redistribution of heavy metals through pollution of the air, water and soil. A common consequence of heavy metal toxicity is the excessive accumulation of reactive oxygen species (ROS) and methylglyoxal (MG), both of which can cause peroxidation of lipids, oxidation of protein, inactivation of enzymes, DNA damage and/or interact with other vital constituents of plant cells. This review focuses on effect of heavy metals on plant growth, yield and their mode of toxic effects in plants.

Copy Right, IJAR, 2017,. All rights reserved.

\section{Introduction:-}

The heavy metal (HM, also referred to in scientific literature as metalloid) contamination of soil is one of the most pressing concerns in the debate about food security and food safety in developing countries like India. Various heavy metals have been reported to be dangerous to the health of humans and wildlife when they occur in the environment at some high concentrations (Martin 1997; Uba et al., 2009). The level of toxic metals is increasing in the agricultural soils due to over utilization of various chemicals for better yields. The pollutants can include metals, organic wastes and other organic and inorganic substances (Shetty and Rajkumar, 2009). (Okunola et al., 2011) summarizes the impact of heavy metal from food origin on human health as well as the mechanism of uptake, transformation and bioaccumulation of heavy metals by plants. Some of the heavy metals are extremely persistent in the environment. They are not easily biodegradable and thus their accumulation reaches to critical levels (Khan et al., 2009). Metals have a high degree of toxicity that can be dangerous for both the human and the environment. The soil pollution by heavy metals has received ample attention in the recent decades (Rafiei et al., 2010). Although low concentrations of these metals are naturally found in soils, human activities have elevated their concentrations. Thus, it is very important to assess soil pollution and take the necessary remediation measures (Romic et al., 2007). Mining, industries, road traffic, waste disposal, and agricultural use of fertilizers and chemicals are amongst human activities that can lead to heavy metal contamination of the soil (Karbassi et al., 2016). On the other hand, main natural factors contributing to metal contamination of the soil include volcanoes, fires in forests, and chemical 
composition of parent materials (Lado et al., 2008). There are several studies in different countries for interpolation and determination of spatial distribution of heavy metals concentrations in soil (Karbassi et al., 2014).

Heavy metals include lead $(\mathrm{Pb})$, cadmium $(\mathrm{Cd})$, nickel $(\mathrm{Ni})$, cobalt $(\mathrm{Co})$, iron $(\mathrm{Fe})$, zinc $(\mathrm{Zn})$, chromium $(\mathrm{Cr})$, iron $(\mathrm{Fe})$, arsenic (As), silver (Ag) and the platinum group elements. Heavy metals are largely found in dispersed form in rock formations. Industrialization and urbanization have increased the anthropogenic contribution of heavy metals in biosphere. Heavy metals have largest availability in soil and aquatic ecosystems and to a relatively smaller proportion in atmosphere as particulate or vapors. Heavy metal toxicity in plants varies with plant species, specific metal, concentration, chemical form and soil composition and $\mathrm{pH}$, as many heavy metals are considered to be essential for plant growth. Some of these heavy metals like $\mathrm{Cu}$ and $\mathrm{Zn}$ either serve as cofactor and activators of enzyme reactions e.g., in forming enzymes/substrate metal complex (Mildvan, 1970) or exert a catalytic property such as prosthetic group in metalloproteins. These essential trace metal nutrients take part in redox reactions, electron transfer and structural functions in nucleic acid metabolism. Some of the heavy metal such as $\mathrm{Cd}, \mathrm{Hg}$ and As are strongly poisonous to metal-sensitive enzymes, resulting in growth inhibition and death of organisms. The inorganic and organic fertilizers (Fertilizer is a substance added to soil to improve plants growth and yield.) are the most important sources of heavy metals to agricultural soil include liming, sewage sludge, irrigation waters and pesticides, sources of heavy metals in the agricultural soils. Others, particularly fungicides, inorganic fertilizers and phosphate fertilizers have variable levels of $\mathrm{Cd}, \mathrm{Cr}, \mathrm{Ni}, \mathrm{Pb}$ and $\mathrm{Zn}$ depending on their sources. Cadmium is of particular concern in plants since it accumulates in leaves at very high levels, which may be consumed by animals or human being. Cadmium enrichment also occurs due to the application of sewage sludge, manure and limes (Yanqun et al., 2005). Although the levels of heavy metals in agricultural soil are very small, but repeated use of phosphate fertilizer and the long persistence, time for metals, there may be dangerously high accumulation of some metals.

\section{Material and Method:-}

This study was designed to determine the status heavy metal in agriculturally fertile soils of Northwestern Himalayas. The study area was delineated into 71 sites and ranging from 3144 to 4600 showing 71 sites (fig. 1) that were selected for the study across different altitudes. Represented soil samples were collected with wooden tools to avoid any contamination of the soils. Three to five pits were dug for each sample. From each pit sample was collected at a depth $0-15 \mathrm{~cm}$ to $15-30 \mathrm{~cm}$. A composite sample of about $1 \mathrm{~kg}$ was taken through mixing of represented soil sample. All composite samples were dried, ground with wooden mottle and passed through $2 \mathrm{~mm}$ sieve. After sieving all the samples were packed in the labeled polythene bags for laboratory investigations. Soil tests were done for heavy metal $(\mathrm{Cd}, \mathrm{Cu}, \mathrm{Pb}, \mathrm{Cr}$ and $\mathrm{Ni})$ at soil testing laboratory, Post Graduate Soil laboratory CSKHPKV, Palampur by using following respective methods: The extractable heavy $(\mathrm{Pb}, \mathrm{Cd}, \mathrm{Cr}$ and $\mathrm{Ni})$ contents of the soil were determined in atomic absorption spectrophotometry Model, Z2300, by taking 1:2 DTPA (0.005M; $\mathrm{pH}$ 7.3).

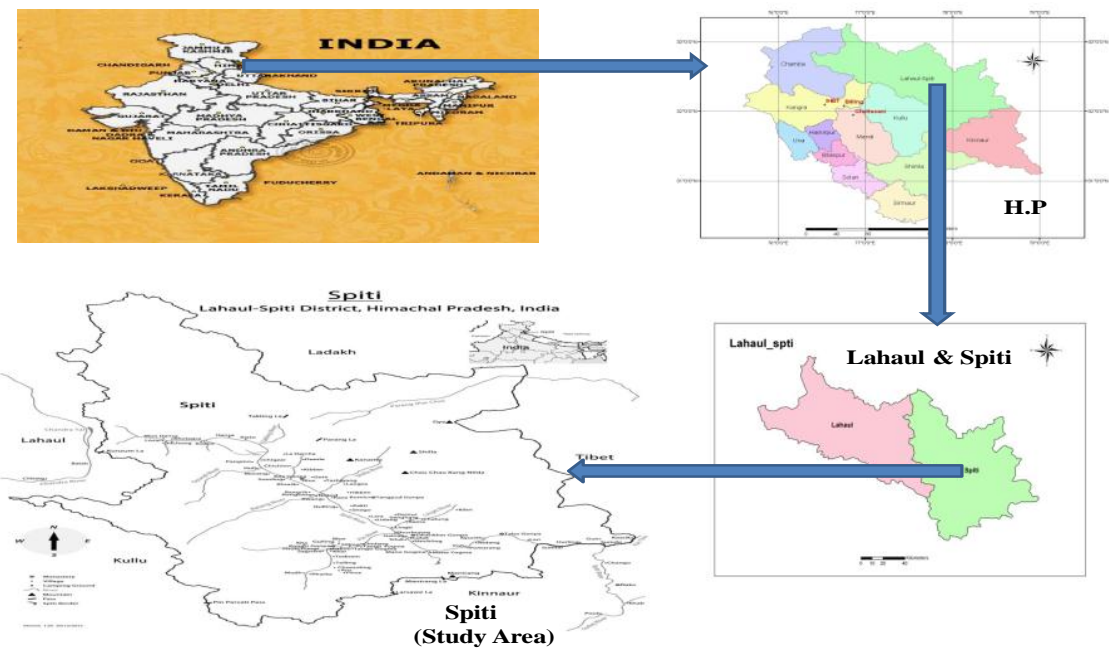

Fig.1:- Map showing study area 
Tabl 1:- Phyto-toxic threshhold of Heavy metals

\begin{tabular}{|c|c|c|c|c|c|}
\hline Heavy metal & Cd & $\mathbf{C u}$ & $\mathrm{Cr}$ & $\mathbf{N i}$ & $\mathbf{P b}$ \\
\hline \multicolumn{6}{|c|}{ Extractable by $0.1 \mathrm{M} \mathrm{HCL},(\mathrm{mg} / \mathrm{kg}$ soil $)$} \\
\hline $\begin{array}{l}\text { Soil database of } \\
\text { heavy metals }\end{array}$ & 1 & 100 & 20 & 40 & 120 \\
\hline $\begin{array}{ll}\text { Soil } & \text { chemical } \\
\text { properties } & \end{array}$ & 0.3 & 21 & 4.2 & 3.4 & 4.2 \\
\hline Ground water quality & 2.3 & 32 & 2 & - & 500 \\
\hline $\begin{array}{l}\text { Activity of soil } \\
\text { micro-organsims }\end{array}$ & 0.45 & 32 & 18 & 25 & 34 \\
\hline $\begin{array}{l}\text { Food quality, safty } \\
\text { and health }\end{array}$ & 0.6 & 50 & 8 & 15 & 40 \\
\hline Overall consideration & 1 & 50 & 30 & 22 & 40 \\
\hline
\end{tabular}

Source: Wing et al., 1994

\section{Results and Discussion:-}

The study clearly depicts that heavy metal status in terms of $(\mathrm{Cd}, \mathrm{Cu}, \mathrm{Pb}, \mathrm{Cr}$ and $\mathrm{Ni}$ ) Table 2 and Table 3 presents the heavy metal concentrations in the cold arid (Spiti) samples. The concentration of extractable micronutrients were found to be in the order $\mathrm{Pb}>\mathrm{Ni}>\mathrm{Cd}=\mathrm{Cr}$ in all agricultural soils of the study area. The extractable copper content of surface soils (Table 2) of Spiti valley under cultivated lands (annual crops), cultivated lands (apple plantation) and pasture lands ranged from 0.50 to $2.24,0.86$ to 1.74 and 0.76 to $1.40 \mathrm{mg} \mathrm{kg}^{-1}$, respectively. However, in the subsurface layers, its values varied from 0.2 to 2.66 for cultivated lands (annual crops), 0.68 to 1.70 for cultivated lands (apple plantation) and 0.66 to $1.46 \mathrm{mg} \mathrm{kg}^{-1}$ for pasture lands (Table 3). The surface soils were having comparatively higher copper content than the subsurface soils and the cultivated land (apple plantation) have more available nitrogen in comparison to cultivated lands (annual crops) and pasture lands. The low content of copper in the soils of Spiti valley might be attributed due to higher content of organic matter in these soils. These results authenticated the earlier findings who have also reported higher $\mathrm{Cu}$ content at the surface and a decreasing trend with depth (Sharma and Kanwar, 2010). Similarly, the value of Cadmium content ranged from 0.17 to $1.72,1.12$ to 1.58 and 0.66 to $1.32 \mathrm{mg}$ $\mathrm{kg}^{-1}$ for the surface soils under cultivated lands (annual crops), cultivated lands (apple plantation) and pasture lands, respectively. In subsurface soils the corresponding values were 0.02 to $0.11,0.03$ to 0.08 and 0.04 to $0.08 \mathrm{mg} \mathrm{kg}^{-1}$ under respective land uses. On average, $\mathrm{Cd}$ concentrations in soils from the Western and North Central states are greater than those from the Northeastern and Southern states the highest concentrations of Cd; Mollisols, Vertisols, Entisols, and Inceptisols are intermediate, and Spodosols, Alfisols and particularly Ultisols are the lowest in total Cd concentrations. The Ultisols and to a lesser extent the Spodosols and Alfisols are more highly leached than the remaining soil orders, and less $\mathrm{Cd}$ in these surface soils may be the result of leaching. Organic soils (Histosols) in the United States are used rather extensively in the production of vegetable crops which require intensive phosphorus fertilization, and the elevated concentrations in this soil order, at least in part, could be due to phosphorus fertilization. Only limited data are available pertaining to concentrations ot cadmium in relation to soil depth. (Pierce et al., 1982). The levels of Chromium ( $\mathrm{Cr}$ ) in surface horizons under cultivated lands (annual crop), cultivated lands (apple plantation) and pasture lands were 0.02 to $0.13,0.04$ to 0.10 and 0.04 to $0.10 \mathrm{mg} \mathrm{kg}^{-1}$, respectively whereas, in the sub-surface layers these values varied from 0.36 to $1.08,0.39$ to 1.17 and 0.35 to $1.10 \mathrm{mg} \mathrm{kg}^{-1}$ for corresponding land uses. The maximum concentration of $\mathrm{Cr}$ was in surface layer soil of which may be due to addition of $\mathrm{Cr}$ in the form of aerosol and gasoline by urban population residing nearby. Immobilisation of metals might have been due to adsorption and occulation on the surface by hydroxides and oxides in soils and tend to remain in the zone of incorporation (Bridge, 1994). Nickel content (Table 2) of the surface samples ranged between 0.01 to $0.67 \mathrm{mg} \mathrm{kg}^{-1}$ in cultivated lands (annual crops), 0.19 to $0.72 \mathrm{mg} \mathrm{kg}^{-1}$ in cultivated lands (apple plantation) and 0.08 to $0.41 \mathrm{mg} \mathrm{kg}^{-1}$ in pasture lands with mean values of $0.22 \pm 0.13,0.38 \pm 0.29$ and $0.19 \pm 0.13 \mathrm{mg} \mathrm{kg}^{-1}$, respectively. Similarly it varied from 0.09 to $2.42,0.19$ to 0.61 and 0.29 to $1.44 \mathrm{mg} \mathrm{kg}^{-1}$ in subsurface (Table 3) layers of cultivated lands (annual crops), cultivated lands (apple plantation) and pasture lands, respectively. The values are in sufficiency range. In surface soils the Ni content was highest in apple plantation soils whereas in subsurface soils its content was highest in pasture soils (Chardot et al., 2007). 
Table 2:- Range \& mean values of heavy metal in surface soils $(0-15 \mathrm{~cm})$ under different land uses in Spiti valley

\begin{tabular}{|c|c|c|c|c|c|}
\hline & \multicolumn{5}{|c|}{ Heavy metal $\left(\mathrm{mg} \mathrm{kg}^{-1}\right)$} \\
\hline & $\mathbf{C u}$ & Cd & $\mathrm{Cr}$ & $\mathbf{N i}$ & $\mathbf{P b}$ \\
\hline \multicolumn{6}{|c|}{ Cultivated lands (annual crops) } \\
\hline Range & $0.50-2.24$ & $0.17-1.72$ & $0.02-0.13$ & $0.01-0.67$ & $0.08-2.70$ \\
\hline Mean & 1.09 & 1.26 & 0.06 & 0.22 & 0.69 \\
\hline SD & 0.30 & 0.22 & 0.02 & 0.13 & 0.57 \\
\hline \multicolumn{6}{|c|}{ Cultivated lands (apple plantation) } \\
\hline Range & $0.86-1.74$ & $1.12-1.58$ & $0.04-0.10$ & $0.19-0.72$ & $0.23-0.67$ \\
\hline Mean & 1.16 & 1.40 & 0.07 & 0.38 & 0.48 \\
\hline SD & 0.50 & 0.16 & 0.03 & 0.29 & 0.22 \\
\hline \multicolumn{6}{|c|}{ Pasture lands } \\
\hline Range & $0.76-1.40$ & $0.66-1.32$ & $0.04-0.10$ & $0.08-0.41$ & $0.28-0.41$ \\
\hline Mean & 0.92 & 1.04 & 0.06 & 0.19 & 0.83 \\
\hline SD & 0.26 & 0.28 & 0.02 & 0.13 & 0.51 \\
\hline
\end{tabular}

Table3:- Range \& mean values of heavy metal in subsurface soils $(15-30 \mathrm{~cm})$ under different land uses in Spiti valley

\begin{tabular}{|c|c|c|c|c|c|}
\hline & \multicolumn{5}{|c|}{ Heavy metal $\left(\mathrm{mg} \mathrm{kg}^{-1}\right)$} \\
\hline & $\mathbf{C u}$ & Cd & $\mathrm{Cr}$ & $\mathbf{N i}$ & $\mathbf{P b}$ \\
\hline \multicolumn{6}{|c|}{ Cultivated lands (annual crops) } \\
\hline Range & $0.2-1.66$ & $0.02-0.11$ & $0.36-1.08$ & $0.09-2.42$ & $0.01-0.64$ \\
\hline Mean & 1.05 & 0.05 & 0.98 & 0.75 & 0.20 \\
\hline SD & 0.17 & 0.02 & 0.51 & 0.57 & 0.12 \\
\hline \multicolumn{6}{|c|}{ Cultivated lands (apple plantation) } \\
\hline Range & $0.68-1.7$ & $0.03-0.08$ & $0.39-1.17$ & $0.19-0.61$ & $0.18-0.69$ \\
\hline Mean & 1.06 & 0.06 & 0.97 & 0.44 & 0.36 \\
\hline SD & 0.55 & 0.02 & 0.43 & 0.22 & 0.28 \\
\hline \multicolumn{6}{|c|}{ Pasture lands } \\
\hline Range & $0.66-1.46$ & $0.04-0.08$ & $0.35-1.10$ & $0.29-1.44$ & $0.08-0.40$ \\
\hline Mean & 0.98 & 0.05 & 0.97 & 0.89 & 0.18 \\
\hline SD & 0.28 & 0.01 & 0.28 & 0.51 & 0.13 \\
\hline
\end{tabular}

\section{Acknowledgement:-}

The authors are highly thankful to Geo Information Centre, CSK H.P.K.V, Palampur, Soil PG Lab assistant for heartfelt help and coordinal support in guiding the authors in a right direction.

\section{Literature Cited:-}

1. Bridge, W.G. 1972. Toxicity levels of mercury lead, copper and zinc in tissue culture systems ofcauliflowers lettucepotato and carrot. Can. J. Bot. 50:973-976.

2. Chardot, V., Echevarria, G., Gury, M., Massoura, S., and Morel, J.L. 2007. Effect on cadmium stress on nitrogen metabolism in nodules and roots of soybean plants. Func. Plant soil. 293: 7-9.

3. Karbassi, A.R., Heidari, M., Vaezi, A.R., Valikhani Samani, A.R., Fakhraee, M. and Heidari, F. 2014. Effect of $\mathrm{pH}$ and salinity on flocculation process of heavy metals during mixing ofaras river water with Caspian Sea water. Environmental Earth Science. 72(2): 457-465.

4. Karbassi, A.R., Tajziehchi, S., Farhang Adib, F. 2016. Role of estuarine natural processes I removal of trace metals under emergency situations. Global Journal of Environmental Science and Management. 2(1): 31-38.

5. Khan, S., Farooq, R., Shahbaz, S., Khan, A.M. and Sadique, M. 2009. Health risk assessmen of heavy metals for population via consumption of vegetables. World Applied Science Journal. 6 (12): 1602-1606.

6. Lado, L.R., Hengl, T. and Reuter, H.I. 2008. Heavy metals in European soils: A geostatistical analysis of the foregs geochemical database. Geoderma. 14(8):189- 199.

7. Martin, C.W. 1997. Heavy metal concentration in flood plain surface soils, Laher River, Germany. Environmental Geology. 30 (1-2):119-125. 
8. Mildvan, A.S. 1970. Metal in enzymes catalysis. In: Boyer DD (ed) The enzymes, vol 11. Academic Press, London, pp 445-536.

9. Okunola, O.J., Alhassan, Y., Yapbella, G.G., Uzairu, A., Tsafe, A.I., Embassey, E. and Abechi, S. 2011. Risk assessment of using mobile phone recharge cards in Nigeria. Journal of Environmental Chemistry and Ecotoxicology. 3(4): 80-85.

10. Pierce, F. J., Dowdy, R. H., and Grigal, D. F. 1982. Concentrations of six trace metals in some major Minnesota soil series. J. Environ. Qual. 11,416-422.

11. Rafiei, B., Nejad, B.M., Hashemi, M. and Khodaei, A.S. 2010. Distribution of heavy metals around the Dashkasan Au Mine. International Journal of Environmental Research. 4(4):647-654.

12. Romic, M., Hengl, T., Romic, D. and Husnjak, S. 2007. Representing soil pollution by heavy metals using continous limitation scores. Comput. Geosci. 3(3): 1316-1326.

13. Sharma, V., and Kanwar, B.B. 2010. Copper status and its relation with soil properties in pea growing soils of high hills dry temprate zone of Himachal Pradesh. Indian Journal of Agricultural Research. 44(1): 32-37.

14. Shetty, R. and Rajkumar, S. 2009. Biosorption of $\mathrm{Cu}$ (II) by metal resistant pseudomonas sp., International Journal of Environmental Research. 3(1):121-128.

15. Uba, S. Uzairu, A. and Okunola, O. J. 2009. Content of heavy metals in lumbricus terrestris and associated soils in dump sites. International Journal of Environmental Research. 3(3): 353-358.

16. Wing, R.S. 1994. Metal toxicity, phytotoxic threshhold of heavy metal and antioxidative defense system in plants. In Reactive Oxygen Species and Antioxidants in Higher Plants, S. D. Gupta, Ed., pp. 177-203.

17. Yanqun, Z., Yuan, L., Jianjun, C., Haiyan, C., Li, Q. and Schratz, C. 2005. Hyper accumulation of Pb, Zn and $\mathrm{Cd}$ in herbaceous grown on lead-zinc mining area in Yunnan, China. Environ. Int. 31:755-762. 